\title{
Genital human papillomaviruses among women of reproductive age in Jamaica
}

\author{
Karen Lewis-Bell, ${ }^{1}$ Silvana Luciani, ${ }^{2}$ Elizabeth R. Unger, ${ }^{3}$ \\ Susan Hariri, ${ }^{4}$ Shelly McFarlane, ${ }^{1}$ Martin Steinau, ${ }^{3}$ Elisa Prieto-Lara, ${ }^{2}$ \\ Andrea S. Vicari, ${ }^{5}$ Beryl Irons, ${ }^{6}$ Merle J. Lewis, ${ }^{7}$ and Jon Kim Andrus ${ }^{8}$
}

Suggested citation Lewis-Bell K, Luciani S, Unger ER, Hariri S, McFarlane S, Steinau M, et al. Genital human papillomaviruses among women of reproductive age in Jamaica. Rev Panam Salud Publica. 2013;33(3):159-65.

ABSTRACT Objective. To characterize the prevalence and distribution of genital human papillomavirus $(H P V)$ types among women in Jamaica, and to explore risk factors associated with HPV infection.

Methods. This was a cross-sectional study that took place in April-July 2010 with 852 sexually-active women, 16-49 years of age, who had attended a selected public or private primary health clinic in one of Jamaica's four health authority regions. Sociodemographic data was collected from each participant by trained study staff. Each participant had a gynecological examination that included a clinical Pap test and a cervical sample for HPV detection and typing - performed using the Research Use Only Linear Array (LA) genotyping assay (Roche Diagnostics Corp., Indianapolis, Indiana, United States). Overall and type-specific prevalence of HPV infection was calculated for 37 HPV types included in the LA genotyping assay. Results. HPV DNA was detected in 460 of the 852 women (54.0\%). Oncogenic HPV was detected in 297 women (34.9\%) and HPV types 16/18 were found in 86 women (10.1\%). The most frequently occurring HPV types were: 16 (6.2\%); 35 (6.0\%); 62 and 83 (5.5\%); 61 and $58(5.4 \%) ; 84(4.7 \%) ; 18(4.3 \%) ;$ and, 66 and 81 (4.2\%). HPV prevalence was highest among women who were single, young (16-19 years), and had had more than three sexual partners in their lifetime.

Conclusions. These results, coupled with high rates of cervical cancer, support introducing HPV vaccines while maintaining and strengthening cervical cancer screening services. Policy decisionmaking that reflects these results is instrumental to establishing a comprehensive cervical cancer program in Jamaica.

Key words Papillomavirus infections, incidence; uterine cervical neoplasms; papillomavirus vaccines; Jamaica; Caribbean region.

\footnotetext{
Immunization Program, Ministry of Health, Kingston, Jamaica.

2 Chronic Disease Prevention and Control Project, Pan American Health Organization (PAHO), Washington, DC, United States of America. Send correspondence to Silvana Luciani, email: lucianis@paho.org.

${ }^{3}$ Center for Emerging and Zoonotic Infectious Diseases, the Centers for Disease Control and Prevention (CDC), Atlanta, Georgia, United States of America.

${ }^{4}$ National Center for HIV, STD, and TB Prevention, CDC, Atlanta, Georgia, United States of America.
}

Human papillomaviruses (HPV), the primary cause of cervical cancer, are the most common sexually transmitted infec-

\footnotetext{
${ }^{5}$ Immunization Project, PAHO, Washington, DC, United States of America.

${ }^{6}$ Caribbean Epidemiology Center, Port-of-Spain, Trinidad and Tobago.

7 Office of the Eastern Caribbean Coordination, PAHO, Bridgetown, Barbados.

${ }^{8}$ Office of the Deputy Director, PAHO, Washington, DC, United States of America.
}

tions. It is estimated that the majority of sexually active people have been exposed to HPV at some point in their lives (1). Although the prevalence and type distribution of HPV vary by geographic area, HPV types 16 and 18 are responsible for approximately $70 \%$ of all cervical cancer cases worldwide (2). These two types are targeted by the currently available prophylactic HPV vaccines. 
Few studies have been undertaken that illustrate HPV prevalence and type distribution in the Caribbean (3-7). In Jamaica, with an estimated cervical cancer incidence rate of 17.4/100 000 and mortality rate of $11.8 / 100000(8)$, the Ministry of Health $(\mathrm{MOH})$ is considering the introduction of an HPV vaccine. Both HPV prevalence and type distribution are important variables to weigh when deciding to introduce an HPV vaccine; therefore, a study was undertaken to better understand these variables among Jamaica's female population of reproductive age. Its objectives were to define the overall prevalence of cervical HPV among sexually-active women in Jamaica, and to explore risk factors associated with HPV infection.

\section{MATERIALS AND METHODS}

\section{Study design and sample}

This was a cross-sectional study conducted over a 12-week period from April-July 2010. It included all four of Jamaica's autonomous regional health authorities (RHAs): North East, South East, Southern, and Western. The study was approved by the Ethical Review Committees of the Ministry of Health of Jamaica, the World Health Organization, and the Centers for Disease Control and Prevention (Atlanta, Georgia, United States; CDC).

The sample size for each RHA was selected in proportion to its population within the age group strata. At least one public and one private clinic were selected from each RHA, and participants represented five public primary health clinics and four private cervical cancer screening clinics operated by the Jamaican Cancer Society (Kingston, Jamaica). Study subjects were recruited in a 1:2 ratio from the private and public sectors, respectively, to represent the actual distribution of family planning and cervical cancer screening services utilization by clinic type, according to Dr. Karen Lewis Bell, Director of the Ministry of Health (personal communication, 30 March 2011). The number of subjects recruited per clinic was relative to the size of the population it served. All of the women who attended the clinics and met the selection criteria were invited by clinic-based health providers to participate. The targets set and obtained were: 117 women from the North
East, 384 from South East, 192 women from Southern, and 144 women from Western.

\section{Study participants}

Eligible study participants were women 16-49 years of age, who were sexually active, not pregnant, and had no history of cervical disease or hysterectomy. The minimum age for the study was 16 years, the age of legal sexual consent in Jamaica. Women were not randomly selected as the study was intended to capture a community-based population that met specific selection criteria.

Participants signed a written consent for participation and were not compensated for their role in the study.

\section{Data collection}

Questionnaire. Each participant completed a confidential questionnaire that was administered privately by trained study staff. The questionnaire collected information on the woman's age, income, level of education, marital status, religious practices, sexual behavior, and reproductive health history. For marital status, "visiting relationship" was defined as having a long-term partner who does not reside in the same house, but spends at least one night per week there.

Prior to the gynecological exam, participants received instruction on cervical cancer risk factors and HPV and were informed that their treatment decisions would be based on the Pap and not the $\mathrm{HPV}$ results, in accordance with the protocols and standards of the $\mathrm{MOH}$.

Screening tests. Each participant had a gynecological examination that included a Papanicolaou (Pap) test, followed by collection of a sample of exfoliated cervical cells in Specimen Transport Media (STM) using the Hybrid Capture 2 DNA collection kit (Qiagen Inc., Valencia, California, United States) for HPV DNA testing. The Pap tests were processed at the University of the West Indies using the Bethesda cytology classification system. The specimens for HPV testing remained at room temperature until the end of the collection day; then they were transported on ice packs to the central laboratory in Jamaica for storage at $-20^{\circ} \mathrm{C}$ and later batch-shipped on dry ice to the CDC.

Follow-up. Women with abnormal or positive Pap test results were referred to a specialist for further evaluation, as per the national cervical cancer guidelines. Any necessary follow-up treatment was delivered at no cost. Those women with high risk HPV DNA types and normal cytology results were followed-up within 6-12 months with a repeat Pap test.

Results of both the Pap and HPV tests were provided to the respective Parish Health Department of the clinic from which each study participant was recruited. The Medical Officers of Health at these Parish Health Departments were then responsible for re-calling any woman with an abnormal Pap test for follow-up and referral to a specialist. They also recalled study participants aged 30 years and older with a positive HPV result who had not had further evaluation as a result of an abnormal Pap test.

\section{Laboratory methods}

DNA isolation. Specimens were thawed immediately prior to extraction. A $200 \mu \mathrm{L}$ aliquot was extracted using automated Chemagic Magnetic Separation Module 1 and ViralNA/gDNA Kit with addition of one hour external lysis at $65^{\circ} \mathrm{C}$ with Proteinase $\mathrm{K}$ in Lysis Buffer Blood (PerkinElmer chemagen Technologie $\mathrm{GmbH}$, Baesweiler, Germany). The final extract ( $100 \mu \mathrm{L}$ total volume) was tested immediately or stored at $-20^{\circ} \mathrm{C}$. For every batch of samples, a water blank was processed through all steps of extraction to serve as a "contamination control."

\section{HPV genotyping test (Linear Array Assay).} HPV detection and typing were performed on all specimens using the Research Use Only Linear Array (LA) genotyping assay (Roche Diagnostics Corp., Indianapolis, Indiana, United States). This assay uses HPV L1 consensus PCR with biotinylated PGMY09/11 primer sets and $\beta$-globin as an internal control for sample amplification. The manufacturer's protocol was modified to use $10 \mu \mathrm{L}$ extract in the $100-\mu \mathrm{L}$ PCR reaction, but was otherwise unchanged.

All samples were hybridized to the typing strip that included probes for 37 HPV types-6, 11, 16, 18, 26, 31, 33, 35, $39,40,42,45,51$, XR-52, 53, 54, 55, 56, $58,59,61,62,64,66,67,68,69,70,71,72$, $73,81,82,83,84,89$, and IS39. Samples positive for the XR probe on the LA HPV strip that were also positive for HPV33, 35 , and 58 required further evaluation to confirm or exclude the presence of 
TABLE 1. Number of women $(n=852)$ enrolled in a genital human papillomavirus prevalence study, by age group and by regional health authority (RHA), Jamaica, 2010

\begin{tabular}{|c|c|c|c|c|c|c|c|c|c|c|}
\hline \multirow{2}{*}{$\begin{array}{r}\text { Age group } \\
\text { (in years) }\end{array}$} & \multicolumn{2}{|c|}{$\begin{array}{c}\text { North East } \\
\text { RHA }\end{array}$} & \multicolumn{2}{|c|}{$\begin{array}{c}\text { South East } \\
\text { RHA }\end{array}$} & \multicolumn{2}{|c|}{$\begin{array}{c}\text { Southern } \\
\text { RHA }\end{array}$} & \multicolumn{2}{|c|}{$\begin{array}{c}\text { Western } \\
\text { RHA }\end{array}$} & \multicolumn{2}{|c|}{$\begin{array}{l}\text { Country } \\
\text { total }\end{array}$} \\
\hline & No. & $\%$ & No. & $\%$ & No. & $\%$ & No. & $\%$ & No. & $\%$ \\
\hline $16-19$ & 15 & 15.6 & 42 & 43.8 & 21 & 21.9 & 18 & 18.8 & 96 & 11.3 \\
\hline $20-24$ & 14 & 11.5 & 54 & 44.3 & 36 & 29.5 & 18 & 14.8 & 122 & 14.3 \\
\hline $25-29$ & 22 & 14.5 & 66 & 43.4 & 37 & 24.3 & 27 & 17.8 & 152 & 17.8 \\
\hline $30-39$ & 34 & 12.5 & 124 & 45.8 & 68 & 25.1 & 45 & 16.6 & 271 & 31.8 \\
\hline $40-49$ & 32 & 15.2 & 97 & 46.0 & 47 & 22.3 & 35 & 16.6 & 211 & 24.8 \\
\hline Total & 117 & 13.7 & 383 & 45.0 & 209 & 24.5 & 143 & 16.8 & 852 & 100 \\
\hline
\end{tabular}

HPV52. An HPV52 quantitative PCR assay was used to determine the status of HPV52 in these cases (9). Samples negative for both $\beta$-globin and HPV were considered inadequate for interpretation and omitted from further analysis.

\section{Statistical analysis}

Analysis was restricted to participants whose cervical specimens were adequate for DNA typing $(n=852)$. Data were analyzed using SAS version 9.1 (SAS Institute, Cary, North Carolina, United States). Confidence intervals (CI) were calculated using Wald or exact (Clopper-Pearson) test for the binomial proportion. Two-sided statistical tests were considered significant at the alpha level of 0.05 .

The overall and type-specific prevalence of HPV infection were calculated with 37 HPV types included in the LA genotyping assay. HPV prevalence was further examined for different risk categories defined as oncogenic-HPV 16, $18,31,33,35,39,45,51,52,56,58,59,66$, and 68; and non-oncogenic-HPV 6, 11, $26,32,40,42,43,44,53,54,55,61,62,64$, $67,69,70,71,72,73,74,81,82,83,84,85$, 87,89 , and IS39.

HPV prevalence was evaluated by risk category within selected demographic, clinical, and other strata. Pearson's chisquare test was used to evaluate bivariate associations between HPV risk groups and selected characteristics; and the Cochran-Armitage test was used to test for age trends. Estimated prevalence and $95 \% \mathrm{CI}$ are presented.

\section{RESULTS}

Of the 934 women recruited for the study, $860(92.0 \%)$ were eligible and agreed to participate. Of the 934 women, 74 were excluded due to: age (outside of the 16-49 years age range); current preg- nancy; hysterectomy; or because they simply declined to participate. Participation rates were high for both public and private clinics (Table 1), ranging from $98.2 \%-100 \%$. Of the 855 women that had the Pap test, 842 tests had valid results; and of the 854 women who had a specimen collected for HPV testing, 852 of those specimens had valid results. A total of 840 women had both a valid HPV and Pap test result.

Sociodemographic and sexual behavioral characteristics are presented in Table 2. The mean age of study participants was 32 years. The majority of participants were in a stable relationship (63.5\% married, visiting, or common law); had at least a secondary school education ( $81.6 \%)$; had become sexually active at 16 years of age or older $(70.2 \%)$; had had three or more lifetime sexual partners $(78.0 \%)$; and had had two or more live births $(66.0 \%)$. The majority of women $(78.0 \%)$ reported income of at least US\$ 116 per month. Among all participants, $71.6 \%$ reported ever having a Pap test, $42.6 \%$ within the past 3 years.

Compared to women from public clinics, those from private clinics were more likely to have a higher level of education; have higher income; be married; have been older at sexual debut (at least 17 years of age); have no or fewer children; and have had a Pap test in the past 3 years $(P<0.05)$.

\section{HPV prevalence}

Among women 16-49 years of age with valid HPV test results, the overall prevalence of any HPV infection was $54.0 \%$ (460/852) (Table 3). HPV detection was highest among women who were single, young (16-19 years), and had had more than three sexual partners in their lifetime. There was no significant difference in overall HPV prevalence by private $(49.6 \%)$ or public $(55.8 \%)$ clinic type. HPV prevalence decreased with age, from $71.9 \%$ among women 16-19 years of age to $42.6 \%$ among those $40-49$ years $(P<0.0001)$ (Figure 1$)$. Co-infection with more than one HPV type was detected in $24.4 \%$ of participants.

\section{Oncogenic HPV types}

Oncogenic HPV was detected in $34.9 \%$ of the participating women (297/852). Prevalence of any 14 oncogenic HPV types significantly decreased with in-

TABLE 2. Characteristics of women $(n=852)$ enrolled in a genital human papillomavirus prevalence study, Jamaica, 2010

\begin{tabular}{|c|c|c|}
\hline \multirow[b]{2}{*}{ Characteristic } & \multicolumn{2}{|c|}{ Overall } \\
\hline & No. & $\%$ \\
\hline \multicolumn{3}{|l|}{ Age (in years) $(n=852)$} \\
\hline $16-19$ & 96 & 11.3 \\
\hline $20-24$ & 122 & 14.3 \\
\hline $25-29$ & 152 & 17.8 \\
\hline 30-39 & 271 & 31.8 \\
\hline $40-49$ & 211 & 24.8 \\
\hline \multicolumn{3}{|l|}{ Marital status ( $n=851$ ) } \\
\hline Single & 181 & 21.3 \\
\hline Married & 155 & 18.2 \\
\hline Common-law & 37 & 4.3 \\
\hline Separated/divorced/widowed & 129 & 15.2 \\
\hline Visiting ${ }^{a}$ & 349 & 41.0 \\
\hline \multicolumn{3}{|l|}{ Education $(n=852)$} \\
\hline Primary school & 139 & 16.3 \\
\hline Secondary school & 526 & 61.7 \\
\hline Diploma or technical school & 94 & 11.0 \\
\hline Some college & 60 & 7.0 \\
\hline College graduate & 33 & 3.9 \\
\hline \multicolumn{3}{|l|}{ Monthly income (in US\$) ( $n=779)$} \\
\hline$<116$ & 172 & 22.1 \\
\hline $116-348$ & 358 & 46.0 \\
\hline $349-581$ & 152 & 19.5 \\
\hline$>581$ & 97 & 12.5 \\
\hline \multicolumn{3}{|l|}{$\begin{array}{l}\text { Age of sexual debut (in years) } \\
\qquad(n=829)\end{array}$} \\
\hline$\leq 15$ & 247 & 29.8 \\
\hline 16 & 186 & 22.4 \\
\hline$\geq 17$ & 396 & 47.8 \\
\hline \multicolumn{3}{|c|}{$\begin{array}{l}\text { Number of lifetime sexual partners } \\
\qquad(n=822)\end{array}$} \\
\hline $1-2$ & 181 & 22.0 \\
\hline $3-5$ & 393 & 47.8 \\
\hline$\geq 6$ & 248 & 30.2 \\
\hline \multicolumn{3}{|l|}{ Parity $(n=852)$} \\
\hline 0 & 98 & 11.5 \\
\hline 1 & 192 & 22.5 \\
\hline 2 & 189 & 22.2 \\
\hline 3 & 149 & 17.5 \\
\hline$\geq 4$ & 224 & 26.3 \\
\hline \multicolumn{3}{|l|}{ Pap test ever $(n=852)$} \\
\hline Yes & 610 & 71.6 \\
\hline No & 242 & 28.4 \\
\hline \multicolumn{3}{|l|}{ Pap test in past 3 years $(n=609)$} \\
\hline Yes & 363 & 59.6 \\
\hline No & 246 & 40.4 \\
\hline
\end{tabular}

a Defined as a long-term relationship with a partner who does not reside in the woman's home, but spends at least one night per week there. 
TABLE 3. Prevalence of human papillomavirus (HPV) by characteristics of women 16-49 years of age, Jamaica, 2010

\begin{tabular}{|c|c|c|c|c|c|c|c|}
\hline & \multirow[b]{2}{*}{ No. } & \multicolumn{2}{|c|}{ Any HPV type } & \multicolumn{2}{|c|}{ HPV 16/18 } & \multicolumn{2}{|c|}{$\begin{array}{c}\text { Other oncogenic } \\
\text { HPV types }\end{array}$} \\
\hline & & $\%$ & $95 \% \mathrm{Cl}$ & $\%$ & $95 \% \mathrm{Cl}$ & $\%$ & $95 \% \mathrm{Cl}$ \\
\hline Overall & 852 & 54.0 & $50.6-57.4$ & 10.1 & $8.1-12.3$ & 24.8 & $21.9-27.8$ \\
\hline \multicolumn{8}{|l|}{ Marital status $(n=851)$} \\
\hline Single & 181 & 54.1 & $46.6-61.6$ & 10.5 & $6.0-15.0$ & 26.0 & 19.7-33.0 \\
\hline Married & 155 & 41.3 & $33.4-49.5$ & 5.8 & $2.7-10.7$ & 14.8 & $9.6-21.4$ \\
\hline Common-law & 37 & 51.4 & $34.4-68.1$ & 2.7 & $0.1-14.2$ & 21.6 & $9.8-38.2$ \\
\hline Divorced/seperated/widowed & 129 & 58.9 & $49.9-67.5$ & 10.9 & $6.1-17.5$ & 26.4 & $19.0-34.8$ \\
\hline Visiting $^{b}$ & 349 & 57.9 & $52.5-63.1$ & 12.3 & $8.9-15.8$ & 28.1 & 23.4-33.1 \\
\hline \multicolumn{8}{|l|}{ Education $(n=852)$} \\
\hline Primary & 139 & 51.1 & $42.5-59.6$ & 10.1 & $5.6-16.3$ & 18.7 & 12.6-26.2 \\
\hline Secondary & 526 & 54.4 & $50.0-58.7$ & 11.0 & $8.5-14.0$ & 26.0 & 22.3-30.0 \\
\hline Diploma & 94 & 56.4 & $45.8-66.6$ & 8.5 & $3.8-16.1$ & 21.3 & $13.5-30.1$ \\
\hline Some college & 60 & 55.0 & $41.6-67.9$ & 6.7 & $1.9-16.2$ & 31.7 & $20.3-45.0$ \\
\hline College graduate & 33 & 51.5 & $33.5-69.2$ & 6.1 & $7.4-20.2$ & 27.3 & $13.3-45.5$ \\
\hline \multicolumn{8}{|l|}{ Monthly income (in US\$) $(n=779)$} \\
\hline$<116$ & 172 & 53.5 & $45.7-61.1$ & 14.0 & $9.2-20.1$ & 24.4 & $18.2-31.54$ \\
\hline $116-348$ & 358 & 52.2 & $46.9-57.5$ & 8.7 & $6.0-12.1$ & 22.6 & 18.3-27.0 \\
\hline $349-581$ & 152 & 48.0 & $39.9-56.3$ & 11.2 & $6.7-17.3$ & 19.1 & 13.2-26.2 \\
\hline$>581$ & 97 & 60.8 & $50.4-70.6$ & 3.1 & $0.6-8.8$ & 35.1 & $25.6-45.4$ \\
\hline \multicolumn{8}{|c|}{ Age at sexual debut (in years) $(n=829)$} \\
\hline$\leq 15$ & 247 & 55.9 & $49.4-62.2$ & 11.7 & $8.0-16.4$ & 23.9 & 18.7-29.7 \\
\hline 16 & 186 & 54.8 & $47.4-62.1$ & 10.2 & $6.3-15.5$ & 25.3 & 19.2-32.1 \\
\hline$\geq 17$ & 396 & 53.5 & $48.5-58.5$ & 9.1 & $6.5-12.4$ & 25.5 & $21.3-30.1$ \\
\hline \multicolumn{8}{|l|}{ Lifetime sexual partners $(n=822)$} \\
\hline $1-2$ & 181 & 60.8 & $53.3-67.9$ & 11.1 & $6.9-16.5$ & 26.0 & 19.7-33.0 \\
\hline $3-5$ & 393 & 52.7 & $47.6-57.7$ & 8.9 & $6.3-12.1$ & 26.0 & $21.6-30.3$ \\
\hline$\geq 6$ & 248 & 51.6 & $45.2-58.0$ & 12.1 & $8.3-16.8$ & 22.6 & $17.5-28.3$ \\
\hline \multicolumn{8}{|l|}{ Parity $(n=852)$} \\
\hline 0 & 98 & 64.3 & $54.0-73.7$ & 7.1 & $2.9-14.1$ & 35.7 & $26.3-46.0$ \\
\hline 1 & 192 & 58.8 & $51.5-65.9$ & 10.4 & $6.5-15.6$ & 30.2 & $23.7-36.7$ \\
\hline 2 & 189 & 56.6 & $49.2-63.8$ & 14.3 & $9.6-20.1$ & 22.8 & $17.0-29.4$ \\
\hline 3 & 149 & 44.3 & $36.2-52.6$ & 11.4 & $6.8-17.6$ & 18.1 & $12.3-25.3$ \\
\hline$\geq 4$ & 224 & 49.5 & $42.8-56.3$ & 6.7 & $3.8-10.8$ & 21.4 & $16.2-27.4$ \\
\hline \multicolumn{8}{|l|}{ Pap test ever $(n=852)$} \\
\hline Yes & 610 & 50.3 & $46.3-54.4$ & 9.5 & $7.3-12.1$ & 20.8 & $17.7-24.3$ \\
\hline No & 242 & 63.2 & $56.8-69.3$ & 11.6 & $7.8-16.2$ & 34.7 & $28.7-41.2$ \\
\hline \multicolumn{8}{|l|}{ Pap test in past 3 years $(n=609)$} \\
\hline Yes & 363 & 51.8 & $46.5-57.0$ & 10.5 & $7.5-14.1$ & 22.0 & $17.9-26.7$ \\
\hline No & 246 & 48.4 & $42.0-54.8$ & 8.1 & $5.0-12.3$ & 19.1 & 14.2-24.0 \\
\hline
\end{tabular}

a Other oncogenic HPV types include: $31,33,35,39,45,51,52,56,58,59,66$, and 68 .

b Defined as a long-term relationship with a partner who does not reside in the woman's home, but spends at least one night per week there.

FIGURE 1. Prevalence of human papillomavirus (HPV) by risk type among women 16-49 years of age, Jamaica 2010

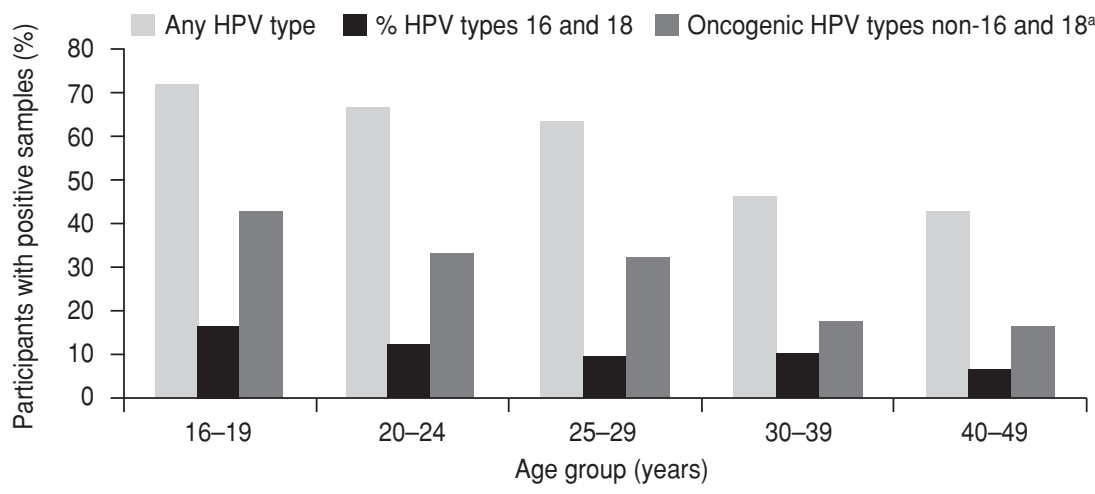

a Other oncogenic HPV types include: 31 , 33, 35, 39, 45, 51, 52, 56, 58, 59, 66, and 68. creasing age, from $59.4 \%$ in the youngest to $22.8 \%$ in the oldest age group $(P<0.0001)$ (Figure 1). Participants who were married, reported higher parity, and ever had a Pap test were less likely to have oncogenic HPV infection. HPV 16 was the most common HPV type (6.2\%); followed by HPV $35(6.0 \%) ; 62$ and 83 (5.5\%); 61 and 58 (5.4\%); 84 (4.7\%); 18 (4.3\%); and, 66 and 81 (4.2\%) (Figure 2).

\section{HPV 16 and 18}

HPV 16 or 18 was detected in $10.1 \%$ $(86 / 852)$ of the study population, and among these $16.3 \%$ were as a single infection. Although not statistically sig- 
FIGURE 2. Human papillomavirus (HPV) type prevalence among women 16-49 years of age, Jamaica, 2010

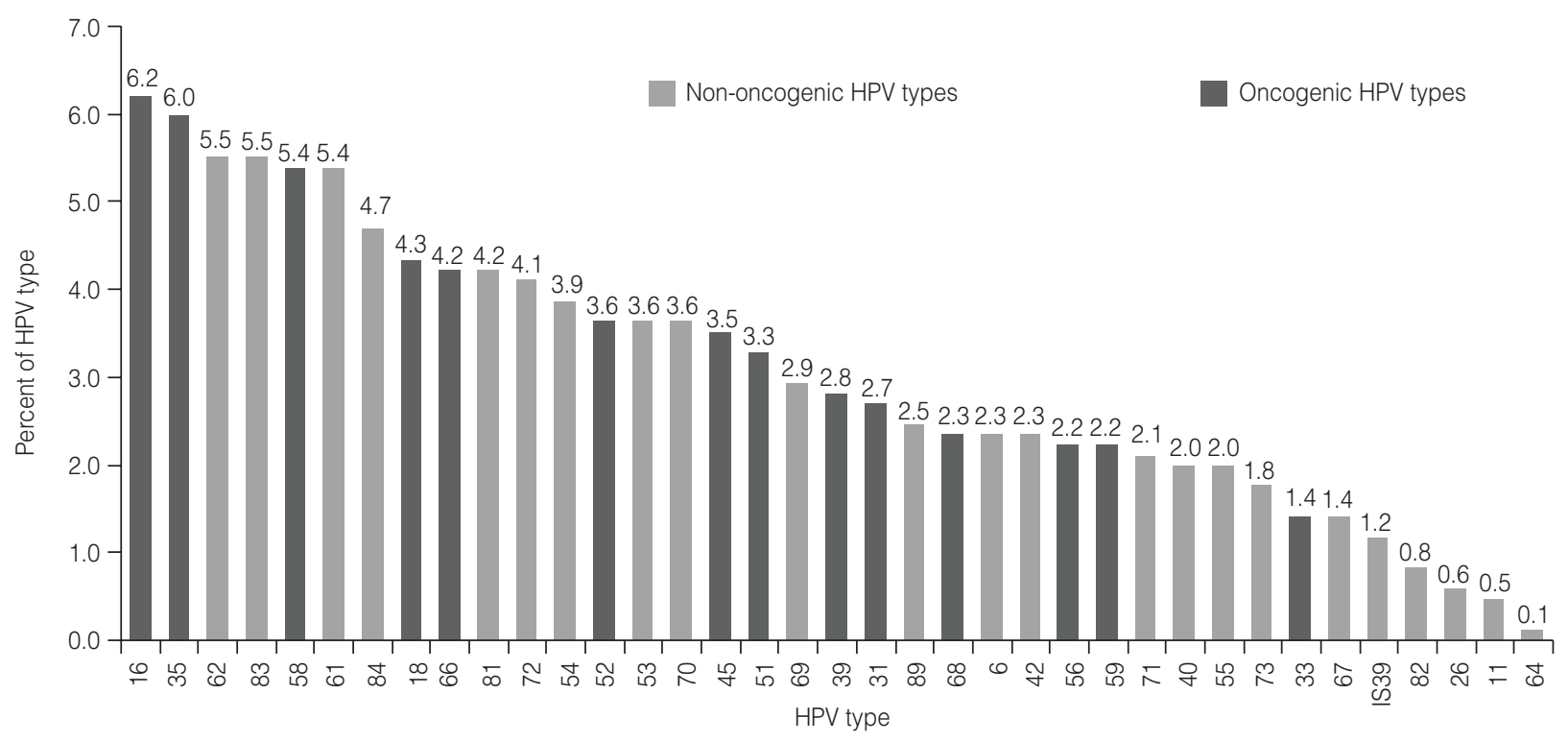

nificant, there was a decreasing trend in the HPV 16/18 prevalence by age group (Figure 1).

\section{HPV and cytology results}

At the time of the study, $89.8 \%$ of women had a normal Pap test result; $3.3 \%$ were diagnosed with atypical squamous cells of undetermined significance/atypical glandular cells of undetermined significance (ASC-US/AGC); $3.9 \%$ were diagnosed with low-grade squamous intraepithelial lesions (LSIL); and only $1.6 \%$ had high-grade squamous intraepithelial lesions (HSIL). There was no significant difference in cytology re- sults between women attending private and public clinics.

Among women with normal cytology, $389(50.8 \%)$ were positive for HPV, a large proportion of whom (234 women; $30.6 \%$ ) were positive for oncogenic HPV types (Table 4).

Among the 75 women with abnormal cytology results, the majority $(84.0 \%)$ were HPV positive. Although the number of women with HSIL was small $(n=14)$, prevalence of HPV16/18 was higher in this group $(50.0 \%)$ as compared to LSIL or ASCUS (21.3\%) and normal cytology (8.4\%). Other oncogenic HPV types (excluding 16/18) accounted for 54\% of LSIL, ASC-US, AGC, versus HSIL at $28.6 \%$.

TABLE 4. Human papillomavirus (HPV) infection by cervical cytology findings among women 16-49 years of age, Jamaica, 2010

\begin{tabular}{|c|c|c|c|c|c|c|c|c|}
\hline \multirow[b]{3}{*}{ HPV status } & \multicolumn{8}{|c|}{ Cervical cytology result } \\
\hline & \multicolumn{2}{|c|}{ Normal } & \multicolumn{2}{|c|}{$\begin{array}{c}\text { ASC-US, }{ }^{a} \\
\text { AGC, }{ }^{b} \text { LSIL }{ }^{c}\end{array}$} & \multicolumn{2}{|c|}{$\mathrm{HSIL}^{\mathrm{d}}$} & \multicolumn{2}{|c|}{ Missing } \\
\hline & No. & $\%$ & No. & $\%$ & No. & $\%$ & No. & $\%$ \\
\hline HPV negative & 376 & 49.2 & 11 & 18.0 & 1 & 7.1 & 4 & 33.3 \\
\hline \multicolumn{9}{|l|}{ HPV positive } \\
\hline HPV 16/18 & 64 & 8.4 & 13 & 21.3 & 7 & 50.0 & 2 & 16.7 \\
\hline Other oncogenic HPV types ${ }^{e}$ & 170 & 22.2 & 33 & 54.1 & 4 & 28.6 & 4 & 33.3 \\
\hline Non-oncogenic HPV types & 155 & 20.3 & 4 & 6.6 & 2 & 14.3 & 2 & 16.7 \\
\hline Total & 765 & 100 & 61 & 100 & 14 & 100 & 12 & 100 \\
\hline
\end{tabular}

atypical squamous cells of undetermined significance.

b Atypical glandular cells.

c Low grade squamous intraepithelial lesion.

d High grade squamous intraepithelial lesion.

e Other oncogenic HPV types include: $31,33,35,39,45,51,52,56,58,59,66$, and 68.

\section{DISCUSSION}

The aim of this study was to determine HPV prevalence and type distribution among Jamaican women 16-49 years of age. HPV DNA was detected in over half of the population (54\%); $35 \%$ of the women studied had at least one oncogenic HPV type and 19\% had only nononcogenic HPV types. This study found HPV prevalence rates higher than those previously reported for Jamaica and other countries in the English-speaking Caribbean (3-7), as well as other parts of the world $(10,11)$. This difference may be attributed to a variety of factors, such as study population and size, specimen collection, and perhaps, more importantly, HPV DNA testing methodology. Standardization of HPV DNA testing methods is necessary for more accurate comparisons among country results.

The relative distribution of HPV types in Jamaica differs from other countries. The top five oncogenic HPV types in Jamaica were found to be: $16,35,58,18$, and 66; whereas, in the United States these were: 16, 51, 52, 66, and 59 (1). Even when compared to other Englishspeaking Caribbean countries, differences are evident in the Jamaica HPV type distribution. In the Caribbean as a whole, HPV 45, 66, 51, 35, and 53 have been reported as most common (12). Yet, a 1988 study in Trinidad found that the most frequently recovered oncogenic 
type was HPV $16(54.5 \%)$, followed by type 18, 35, and 45; and a 2011 study in the same country found HPV 52, 66, 16,18 and $58(4,7)$. Some of these differences may be attributed to the age groups studied and specimen collection methods used. Another study of the Caribbean as a whole (12) found HPV 35 to be higher in Jamaica than in the other countries.

In the present study, types 16 and 18 were found alone, or with other HPV types in $10 \%$ of women. HPV 16 was found to be the most common type detected among the population screened, as well among women with cervical pre-cancer (HSIL), which is in contrast to other studies of HPV in Jamaica (12). The present study also found that HPV $16 / 18$ prevalence in Jamaica was higher than that stated by other studies of the English-speaking Caribbean and the United States $(7,13)$. The high proportion of HPV16/18 types found among a general population and HSIL may be good predictors of the fraction of cervical cancers that are caused by these types. $^{9}$

As seen in similar studies from other countries, HPV prevalence in Jamaica was found to be age-dependent and highest in the younger age group $(2,10$, 14). Some studies report a clear second HPV peak after 45 years of age, but this was not observed despite the upper age limit of 49 years (10). A lower risk was found for married women, especially for oncogenic HPV types, including 16/18; but a higher risk was found for oncogenic HPV in women with a "visiting" relationship. Unlike other studies on HPV risk factors (14), no relation-

\footnotetext{
${ }_{9}^{9}$ Bruni L, Alemany L, Diaz M, Tous S, Castellsague $\mathrm{X}$, Bosch FX. HPV-16 in women correlates with hpv16 fraction in cervical cancer. Abstract presented at the Proceedings of the 27th International Papillomavirus Conference and Clinical Workshop. Berlin, Germany, 17-22 September 2011.
}

ship was found between lower income, lower education, increased number of sexual partners, and higher parity and increased risk for HPV infection. The reasons for this are not entirely clear, but a possible hypothesis is mentioned in the study limitations.

\section{Study limitations}

One of the strengths of this study was the large number of women of reproductive age from all across Jamaica; however, the results may be biased by the fact that participants were already attending health clinics, and thus demonstrating health-seeking behavior that is not truly representative of all women of this age in Jamaica. Also, being a crosssectional study, the results do not reflect the duration of infection.

\section{Conclusions}

In conclusion, this is the largest study of women from a population-based sample that participated in cervical cancer screening in Jamaica and that used a validated and well-known method of HPV testing conducted by a highlyexperienced laboratory. The results will enhance the overall understanding of HPV prevalence in Jamaica, and possibly, in other Caribbean countries. It will be used as part of an overall policy decision-making process for HPV vaccine introduction, a process that will also include an HPV vaccine acceptability study, cost effectiveness analysis, HPV testing in cervical cancer cases, sensitization of key stakeholders, and strengthening of the cervical cancer prevention and control program (15). Jamaica is the first country in the English-speaking Caribbean to undertake such a comprehensive review of evidence for informed decision-making for HPV vaccines.
The disease burden, HPV prevalence, and HPV type distribution all support introducing HPV vaccines within a comprehensive cervical cancer program in Jamaica. Types 16/18 are common types in Jamaica, especially among females 16-19 years of age, and important for currently available vaccines; however, there are other very common types that should be monitored, especially HPV35. The next step will be to investigate and better understand HPV types among the sub-group of women with cervical cancer. In addition, it is critically important to strengthen the cervical cancer screening program, especially among women with no history of prior screening.

Acknowledgements. The authors wish to thank J. Peter Figueroa for his review and guidance on the study; Wendel Guthrie for his clinical support in re-training the field nurses; the field nurses who collected samples for the HPV study; the Ministry of Health of Jamaica for support with project execution and for use of its clinical facilities for data collection; the Jamaica Cancer Society (Kingston, Jamaica) for use of its clinic facilities for data collection; the Centers for Disease Control and Prevention (Atlanta, Georgia, United States) for in-kind support with processing of HPV DNA tests; and the staff of the Pan American Health Organization/World Health Organization in Jamaica for administrative support.

Funding. This study was funded by a generous grant from the Sabin Vaccine Institute (Washington, DC, United States). The funding organization did not have any involvement in the study nor in the preparation of the manuscript.

\section{Conflicts of interest. None.}

\section{REFERENCES}

1. Hariri, S Unger ER, Sternberg M, Dunne EF, Swan D, Patel S, et al. Prevalence of genital human papillomavirus among females in the Unites States, the National Health and Nutrition Examination Survey, 2003-2006. J Infect Dis. 2011;204(4):566-73.

2. Bosch FX, Burchell AN, Schiffman M, Giuliano AR, de Sanjose S, Bruni L, et al. Epidemiology and natural history of human papillomavirus infections and type- specific implications in cervical neoplasia. Vaccine. 2008;26S:K1-16.

3. Figueroa JP, Ward E, Luthi TE, Vermund $\mathrm{SH}$, Brathwaite AR, Burke RD. Prevalence of human papillomavirus among STD clinic attenders in Jamaica: Association of younger age and increased sexual activity. Sex Trans Dis. 1995;2:114-8.

4. Lewis MJ. Human papillomavirus infections and other risk factors as deter- minants of cervical intraepithelial neoplasia in Trinidad and Tobago, West Indies [MPH dissertation]. Baltimore (Maryland): Johns Hopkins University; 1988.

5. Rattray C, Strickler HD, Escoffery C, Cranston B. Type specific prevalence of human papilomavirus DNA among Jamaican colposcopy patients. J Infect Dis. 1996; 173:718-21. 
6. Watt A, Garwood D, Jackson M, Younger N, Ragin C, Smikle M, et al. High-risk and multiple human papillomavirus (HPV) infections in cancer-free Jamaican women. Infect Agent Cancer. 2009; 4 Suppl 1:S11.

7. Andall-Brereton GM, Hosein F, Salas RA, Mohammed W, Monteil MA, Goleski V, et al. Human papillomavirus genotypes and their prevalence in a cohort of women in Trinidad. Rev Panam Salud Publica. 2011;29(4): 220-6.

8. Ministry of Health, Jamaica. Public Health Information. Kingston, Jamaica: Government of Jamaica; 2011.

9. Onyekwuluje JM, Steinau M, Swan DC, Unger ER. A real time PCR assay for HPV 52 detection and viral load quantification. Clin Lab. 2012;58(1-2):61-6.
10. Bruni L, Diaz M, Castellsagué X, Ferrer E, Bosch FX, de Sanjosé S. Cervical human papillomavirus prevalence in 5 continents: Meta-analysis of 1 million women with normal cytological findings. J Infect Dis. 2010;202(12):1789-99.

11. De Vuyst H, Clifford G, Li N, Franceschi S. HPV infection in Europe. Eur J Cancer. 2009;45(15):2632-9.

12. Ragin C, Watt A, Markovic N, Bunker $\mathrm{CH}$, Edwards RP, Eckstein S, et al. Comparisons of high-risk cervical HPV infections in Caribbean and US populations. Infect Agent Cancer. 2009;4(Suppl 1):S9.

13. Dunne EF, Sternberg M, Markowitz LE, McQuillan G, Swan, D, Patel S, et al. Human Papillomavirus (HPV) 6,11,16, and 18 prevalence among females in the United States-National Health and Nutrition Examination Sur- vey, 2003-2006: opportunity to measure HPV vaccine impact? J Infect Dis. 2011;204(4): 562-5.

14. Almonte $M$, Albero $G$, Molano $M$ Carcamo C, García PJ, Pérez G. Risk factors for human papillomavirus exposure and co-factors for cervical cancer in Latin America and the Caribbean. Vaccine. 2008;26 (Suppl 11):L16-36.

15. Andrus JK, Jauregui B, De Oliveira LH, Ruiz-Matus C. Challenges to building capacity for evidence-based new vaccine policy in developing countries. Health Aff. 2011;30(6): 1104-12.

Manuscript received on 29 September 2012. Revised version accepted for publication on 25 January 2013.

RESUMEN Objetivo. Determinar la prevalencia y la distribución de los tipos de virus de los papilomas humanos (VPH) genitales en las mujeres de Jamaica y explorar los factores de riesgo asociados con la infección por VPH.

\section{Virus de los papilomas humanos genitales en mujeres en edad reproductiva de Jamaica}

Palabras clave
Métodos. Este estudio transversal se llevó a cabo de abril a julio del 2010. Participaron 852 mujeres sexualmente activas, de 16 a 49 años de edad, que acudieron a uno de los consultorios públicos o privados de atención primaria seleccionados en cada una de las cuatro autoridades sanitarias regionales de Jamaica. Personal capacitado del estudio recopiló datos sociodemográficos de cada participante. Todas las participantes fueron sometidas a un examen ginecológico que comprendía una prueba clínica de Papanicolaou y la obtención de una muestra del cuello uterino a efectos de detectar y tipificarlos VPH mediante la prueba de genotipado Linear Array (LA) (Roche Diagnostics Corp., Indianápolis, Indiana, Estados Unidos), de uso exclusivo en investigación. Se calcularon las prevalencias global y específica de tipo de la infección por VPH para los 37 tipos de VPH incluidos en la prueba de genotipado LA.

Resultados. Se detectó ADN de VPH en 460 de las 852 mujeres (54,0\%). Se detectaron VPH oncógenos en 297 mujeres (34,9\%), y VPH de los tipos 16 y 18 en 86 mujeres $(10,1 \%)$. Los tipos de VPH detectados con mayor frecuencia fueron $16(6,2 \%), 35$ $(6,0 \%), 62$ y $83(5,5 \%), 61$ y $58(5,4 \%), 84(4,7 \%), 18(4,3 \%)$, y 66 y $81(4,2 \%)$. La prevalencia de VPH fue más elevada en mujeres solteras, jóvenes (de 16 a 19 años) y que habían tenido más de tres compañeros sexuales en sus vidas.

Conclusiones. Estos resultados, junto a las elevadas tasas de cáncer cervicouterino, fundamentan la introducción de las vacunas contra el VPH al tiempo que se mantienen y refuerzan los servicios de tamizaje del cáncer cervicouterino. Las decisiones políticas que se adopten como consecuencia de estos resultados serán determinantes para establecer un programa integral contra el cáncer cervicouterino en Jamaica.

Infecciones por papillomavirus; incidencia; neoplasias del cuello uterino; vacunas contra papillomavirus; Jamaica; región del Caribe. 